\title{
ЦИФРОВИЗАЦИЯ, АККРЕДИТАЦИЯ И МОДЕРНИЗАЦИЯ ВУЗОВ
}

\author{
Бобкова И.А.
}

Работа посвящена анализу мер, предпринятых для реализачии программы по иифровизации российской экономики в части направления развития «Кадры и образование», в том числе взаимовлиянию аккредитации вузов и цчифровизациии образования.

DOI: $10.20537 /$ mce2020econ 17

Введение. Программа «Цифровая экономика Российской Федерации» [1] является главным документом, на основании которого осуществляется реформирование системы высшего образования с точки зрения перевода ее в цифровую среду. Система образования может рассматриваться как краеугольный камень модернизации всей экономики России в этом контексте. Модернизация высшего образования стала вторым этапом этого процесса. В школах процесс активной цифровой трансформации начался раньше, чем в вузах [2]. Первые результаты показали, что переход на цифровое образование будет проходить долго и не совсем однозначно.

Государственные документы, направленные на ускорение цифровизации. В последние годы был принят ряд документов, на основании которых происходит перестройка экономики. Первый шаг - присоединение России к Окинавской хартии глобального информационного общества (2000 г.). Следующие шаги по пути в цифровое общество - «Стратегия развития информационного общества в РФ» (2007 г.), ратификация в 2015 г. Договора о Евразийском экономическом союзе, в котором предусмотрено создание интегрированной информационной системы. В 2016 г. выходят Указы Президента РФ № 642 «О Стратегии научнотехнологического развития Российской Федерации» и № 646 «Доктрина информационной безопасности Российской Федерации». В 2017 г. принимается Программа «Цифровая экономика Российской Федерации» [1], определившая конкретные меры и ответственность государственных 
структур за различные направления развития, а в 2019 г. принимаются поправки к ней — корректировка до 2030 г.

В Программе определена главная цель ближайшего периода - создание целостной системы цифровой экономики России, в том числе создание условий институционального и инфраструктурного характера, устранение препятствий и ограничений для создания и развития высокотехнологичного бизнеса. Также выделены три уровня цифровизации: рынки и отрасли экономики; платформы и технологии; среда, которая создает условия для развития платформ и технологий.

Готова ли Россия к такой трансформации? В исследовании Всемирного экономического форума (2018 г. - индекс сетевой готовности, [3]) по оценке готовности стран к цифровой экономике РФ занимает 41 место; по инновационным результатам использования цифровых технологий — 38-е; по инвестициям в инновации и конкурентоспособности экономики - 43-е.

В Международном индексе I-DESI анализируется развитие цифровой экономики стран ЕС в сравнении с другими 17 странами (2018 г., [4]). Основные компоненты этого индекса: связь, человеческий капитал, использование интернета, внедрение цифровых технологий в бизнесе и цифровые услуги для населения. По общему индексу РФ занимает 14 место, по доступности фиксированной широкополосной связи - 2-е (по другой оценке - последнее); по состоянию человеческого капитала 10-е; по частоте использования сети Интернет - 14-е; по внедрению цифровых технологий предприятиям в бизнесе - РФ заняла последнее место; по предоставлению цифровых услуг для населения, созданию цифрового правительства - 16-е. Наибольшие претензии, которые высказываются в наш адрес - недостаточная нормативной база и плохие условия для ведения бизнеса с применением цифровых технологий.

Выделяют пять направлений развития цифровой экономики: нормативное регулирование; кадры и образование; формирование исследовательских компетенций и технических заделов; информационная инфраструктура; информационная безопасность.

Кадры и образование. В направление «Кадры и образование» включают вопросы создания ключевых условий для подготовки кадров цифровой экономики, совершенствования системы образования, обеспечивающей цифровую экономику компетентными кадрами, формирования рынка труда, опирающегося на требования цифровой экономики. 
Важным вопросом является создание системы мотивации по участию кадров в развитии цифровой экономики.

Развитие направления «Кадры и образование» Программы определяется следующими показателями.

1) Обеспечение цифровой экономики компетентными кадрами:

а) доля государственной итоговой аттестации выпускников, проходящей с использованием цифровых информационных технологий должна к 2020 г. достигнуть 15 \%, к 2024 г. - 100\% (в 2019 г. 12\%);

б) оценка качества российского школьного образования в рейтинге PISA - в 2020 место РФ в рейтинге должно не ниже 20, в 2024 не ниже 12 (в 2018 г. РФ занимает 31-33 места [5], хотя Москва заняла 3-6 места (впервые выделена отдельной строкой);

в) количество выпускников системы среднего профессионального образования с базовыми компетенциями цифровой экономики - к 2024 г. должно составить 800 тыс. человек в год, в 2020 г. - 300 тыс.; г) количество выпускников системы высшего образования по ИТспециальностям должно к 2024 г. составить 120 тыс., в 2020 г. - 80 тыс. (в 2019 г. система высшего образования выпустила примерно 46 тыс. специалистов в области ИТ (26.8 тыс. - бюджет), увеличенный план приема на 2020 г. - 45.7 тыс. бюджетных мест).

2) Создание условий для подготовки кадров цифровой экономики: доля граждан, использующих так называемую персональную траекторию развития, должна к 2024 г. составить $60 \%$, а доля обучающихся, выбирающих для получения компетенций индивидуальные траектории обучения - $100 \%$.

3) Показатели изменения рынка труда:

a) количество специалистов, прошедших переобучение в рамках дополнительного образования к 2024 г - 1 млн человек, к 2020 г. - 0.5 млн (в 2019 г. - 66 тыс. человек, с учетом постоянно растущих темпов развития онлайн-образования [6] возможно достижение объемов примерно в 700 тыс. человек);

в) доля крупных и средних компаний, использующих для работы с сотрудниками персональную траекторию развития - 50 \% (по нашему мнению, нереальная цифра на данном этапе);

г) доля преподавательского состава, переподготовленного для обучения компетенциям цифровой экономики - 100\% к 2021 г. (в 2018 г. их было всего $27 \%$, но достичь $100 \%$ в 2021 г., по-видимому, можно, так как выдача «липовых» удостоверений идет полным ходом). 
4) Создание системы мотивации по участию в развитии цифровой экономики, например, обеспечение России места в рейтинге привлечения талантов The Global Talent Competitiveness Index не ниже 30-го к 2024 г. и не ниже 50-го к 2020 г. (в 2018 г. РФ заняла 56 место, в 2019 г. — 48-е [7]).

Цифровизация в вузах. Компьютеризация увеличивает эффективность взаимодействия подразделений на уровне всего вуза, что необходимо для всех инновационных преобразований. Срочность и необходимость перехода на новые технологии подтвердила ситуация с коронавирусом 2020 г. Переход на дистанционное образование в авральном режиме заставил многие вузы пересмотреть свои ресурсы, обеспечить срочное расширение сфер применения цифровых технологий в рамках университетов.

\section{Сферы, подлежащие цифровизации в вузах.}

1. Научно-педагогические работники, студенты, администрация университета, выпускники и абитуриенты и др.

2. Базовые информационные сервисы - создание единого информационного пространства для цифрового взаимодействия внутри университета с использованием видеоэкранов, цифровых досок, беспроводной связи, облачных хранилищ и т.п.

3. Сервисы, облегчающие каждодневную жизнь студентов, педагогов и администрации в современном университете (цифровая библиотека, современные методы обработки больших массивов данных, определение перспективных научных направлений и т. п).

4. Сервисы, увеличивающие финансовую независимость вуза (цифровой маркетинг, управление исследовательскими проектами, финансовые взаимоотношения с абитуриентами и студентами и т.п.).

5. Система управления вузом, интегрированным в цифровую экономику, в том числе и изменение структуры университета.

Специальности, по которым выпускают студентов. В России на данный момент ИТ-специальности имеют 344 вуза (бакалавриат), а именно: прикладная математика и информатика, ИВТ, ИСиТ, информационная безопасность, бизнес-информатика, системы связи, робототехника и мехатроника, управление в различных системах и некоторые другие. В 2020 г. российские региональные университеты должны выпустить около 26.5 тыс. специалистов по ИТ-специальностям [8]. Университеты Москвы и Санкт-Петербурга выпускают около 15 тысяч специалистов ежегодно. Лидерами по выпуску и приросту выпуска стали: Ростов-на-Дону, Уфа, 
Самара, Новосибирск, Воронеж. Лидеры-вузы в Москве: МФТИ, МТУСИ, МИСиС, МИРЭА, МЭИ, РЭУ, в Санкт-Петербурге - СПбГУТК, ИТМО.

Наибольший прирост выпускников в 2020 г. - по специальностям информационно-аналитические системы безопасности, ИВТ, математика и механика, администрирование ИС (свыше 200\%), близки к ним информационная безопасность, программная инженерия, прикладные математика и физика, математическое моделирование (свыше 170-190\%). Но недостаток последних лет - уменьшение выпуска в магистратуре.

Финансирование программы цифровизации. Финансирование программы цифровизации до 2024 г. запланировано в объеме 1.6 трлн руб. (хотя в 2019 г. обещали добавить еще 1 трлн руб. [9] и изначально расходы на эту программу экспертами были оценены в 3.5 трлн руб.). Источники финансирования: 1099 млрд руб. - федеральный бюджет, 535.3 млрд руб. - внебюджетные источники. Особое внимание придается технопаркам. Строятся огромные парки у МГУ и МФТИ на отдельных территориях, выделенных городом. Даже университеты, не входящие в Топ10, получили гранты на создание современных лабораторий (подобие технопарков). На кадровое обеспечение в 2019 г. было выделено 143 млрд.руб. до 2024 г. (в том числе 138 млрд. из средств госбюджета) [10]. На сайте [11] представлено распределение этих средств по годам и министерствам (Минобрнауки РФ и Минпросвещения РФ выделяется около $4 \%$ от всей суммы, Минкомсвязи РФ - около $40 \%$ ).

Цифровой университет. Одним из приоритетных направлений работы Минобрнауки РФ с 2018 г. стало формирование «Современой цифровой образовательной среды» («Цифровая школа». «Цифровой университет»). С точки зрения министерства, современный цифровой университет - это: адаптация онлайн-обучения к нуждам цифровизации, развитие онлайн-курсов; развитие цифровых библиотек и цифровых кампусов; разработка программ цифровой трансформации каждым университетом для перехода к новой образовательной и научноисследовательской модели; глобализация образовательной деятельности с привлечением информационных технологий (увеличение доли иностранных студентов и преподавателей; зарубежная публикационная активность, создание открытых международных кампусов, привлечение иностранных ученых, организация зарубежных стажировок и т.п.).

Современный университет имеет достаточно сложную структуру. Для полноценной модернизации с позиций погружения вуза в цифровую среду, университетам нужно провести ряд следующих преобразований: 
- модернизировать системы управления: ректорат, деканаты (институты), кафедры;

- ИТ-подразделения вузов должны предоставлять максимально удобный доступ к информационным ресурсам для всех работников университета и студентов в соответствии с особенностями обучения (очная, заочная формы, бакалавриат, магистратура, аспирантура, колледж и т.п.);

- кадровые службы должны обеспечить разработку и поэтапную реализацию программы подготовки персонала к внедрению новых технологий, включая повышение квалификации.

Аккредитация вузов в условиях цифровизации. В последние годы многие университеты проходили аккредитацию, которая в большинстве случаев совпала с активным процессом внедрения ИТтехнологий в вузе. Во многих вузах активное внедрение цифровых технологий было одним из требований комиссий по аккредитации. Для профессорско-преподавательского состава, ИТ-специалистов, административных подразделений университетов «цифровизация плюс аккредитация» превратилась в стихийное бедствие. Постоянно менялись «правила игры», из разных структур поступали разные, иногда взаимоисключающие указания. Каждые пару месяцев происходили кардинальные изменения в информационно-компьютерной среде. Педагоги забыли о существовании свободного времени, семьи, о домашних заданиях и контрольных. Рефераты и курсовые работы проверялись «по диагонали», студенты были заброшены.

Похожая ситуация возникла в марте 2020 г. в связи с уходом университетов на дистанционное обучение во время эпидемии коронавируса. Вынужденный карантин продемонстрировал потребность в оцифровке материалов преподавателей, библиотечных ресурсов, разработке информационно-техническими отделами университетов собственных ИТмоделей и адаптации существующих программных продуктов. Преподаватели вузов по всей стране сели за презентации, тесты и видео-лекции. В основном, они достойно закончили этот сложный год, постаравшись максимально сохранить качество образования. Но это было сделано титаническими усилиями. Можно сказать, что преподаватели школ и вузов совершили настоящий подвиг, бросив все силы на вытаскивание своих учеников из ужасающей ситуации, в которой они оказались из-за режима изоляции. 
Заключение. Отрицательное отношение многих преподавателей к цифровизации образовательных учреждений связано не с очередным витком научно-технического прогресса как таковым, а с организационной стороной его реализации. Система образования очень чувствительна к техническому несовершенству внедряемых систем. Студентам и школьникам нужны цифровые учебники и виртуальная реальность, уроки, объединенные в единую интегрированную систему с межпредметными связями. Преподавателям нужны индивидуальные задания, качественные электронные библиотеки, ИВС под нужды конкретной дисциплины, адекватные системы для создания видеоматериалов и всеобщий равный доступ в технопарки.

Хотя цифровые технологии все больше проникают в ежедневную жизнь университетов, вузы находятся только в самом начале пути. Чтобы реализовать намеченную Программу цифровизации, придется глубоко трансформировать высшую школу. Однако, эта трансформация невозможна без разработки четкой и внятной стратегии цифровизации, учитывающей специфику каждого конкретного вуза.

\section{СПИСОК ЛИТЕРАТУРЫ}

1. Паспорт национального проекта "Национальная программа "Цифровая экономика Российской Федерации" (утв. президиумом Совета при Президенте РФ по стратегическому развитию и национальным проектам, протокол от 04.06.2019 №7). URL: http://www.consultant.ru/document/cons_doc_LAW_328854/

2. Бобкова И.А. Цифровизация образования: начальный этап // Научнопрактический журнал «Кониепџии». 2018. № 1 (37). С.72-78.

3. Россия в зеркале международных рейтингов / Информационно-справочное издание / Отв. ред. В.И. Суслов, научные редакторы О.В. Валиева, Н.А. Кравченко, ИЭОПП СО РАН. - Новосибирск: Параллель, 2019.

4. Shaping Europe's digital future: International Digital Economy and Society Index 2018. European Commission Report /Study of 26.10.2018. URL: https:/ec.europa.eu/digital-single-market/en/news/international-digitaleconomy-and-society-index-2018

5. PISA 2018 Results: Combined Executive Summaries. URL: https://www.oecd.org/pisa/Combined_Executive_Summaries_PISA_2018

6. Онлайн-образование (рынок России) // J'son \& Partners Consulting Report of 2019/10/04. URL: https://www.tadviser.ru/index.php/Статья:Онлайнобразование_(рынок_России 
7. 2020 Global Talent Competitiveness Index / GTCI Report, 2020. URL: https:/gtcistudy.com/

8. Рост кадрового потенциала ИТ-отрасли в регионах вызывает беспокойство (Совместное исследование РУССОФТ и Клуба «IT-Планета»-2019). URL: https://russoft.org/analytics/sovmestnoe-issledovanie-russoft-i-kl/

9. Жабин Н. Д. Медведев: «Цифровая экономика» потребует свыше 1.6 трлн руб. // портал Neftegaz.RU от 4 июня 2019. URL:

https://neftegaz.ru/news/tsifrovizatsiya/452663-d-medvedev-tsifrovayaekonomika-potrebuet-svyshe-1-6-trln-rub/

10. Финансирование национального проекта «Цифровая экономика» https://www.tadviser.ru/index.php/Статья:Финансированияе_программы_Ци фровая_экономика

11. Издание itWeek. URL: https://www.itweek.ru

\section{DIGITALIZATION, ACCREDITATION AND MODERNIZATION OF UNIVERSITIES}

\section{Bobkova I.A.}

The paper is devoted to the analysis of measures taken to implement the program of digitalization of the Russian economy in terms of the development direction "Personnel and education", including the mutual influence of accreditation of universities and digitalization of education. 